\title{
Manubriosternal dislocation type II associated with thoracic spine fracture: What can we learn from this?
}

\author{
N N M Razafimanjato, ${ }^{1}$ MD; T D N Ravelomihary, ${ }^{2}$ MD; N O N L H Rajaonarison, ${ }^{2}$ MD; A Ahmad, ${ }^{2} \mathrm{PhD} ; \mathrm{H} \mathrm{J} \mathrm{L} \mathrm{Rakotovao,}^{1} \mathrm{PhD}$ \\ ${ }^{1}$ Thoracic Surgery Unit, Joseph Ravoahangy Andrianavalona Hospital and Faculty of Medicine, University of Antananarivo, Madagascar \\ ${ }^{2}$ Imaging Medical Centre, Joseph Ravoahangy Andrianavalona Hospital and Faculty of Medicine, University of Antananarivo, Madagascar
}

Corresponding author: N N M Razafimanjato (razafesteban@yahoo.fr)

\begin{abstract}
Traumatic dislocation of the manubriosternal joint is rare, and management correction requires an individualised decision. We report a case of a young female who suffered a type II manubriosternal dislocation with concomitant thoracic spine fracture, as a result of a motor vehicle accident. The mechanism and various therapeutic outcomes are discussed, and a review of the literature provided.
\end{abstract}

Afr J Thoracic Crit Care Med 2019;25(3):127-129. https://doi.org/10.7196/AJTCCM.2019.v25i3.005

Type II manubriosternal dislocations with concomitant spinal fracture are extremely rare, and may be associated with thoracic visceral injuries. There are very few published case reports. ${ }^{[1-3]}$ There is no definite standard for treating such injuries, and in practice, the thoracic surgeon often has difficulty choosing and planning surgical technique(s). We describe a case of a young woman with traumatic manubriosternal dislocation. In this literature review, the main pathophysiological mechanism of traumatic manubriosternal dislocation and spine fracture, and their treatments, are discussed.

\section{Case report}

A 22-year-old woman was admitted to our emergency department as a result of a motor-vehicle accident. At presentation, the patient had stable vital signs. She was semi-conscious with a Glasgow Coma Score (GCS) of 15, and a palpable deformity at the manubriosternal joint that was tender to the touch. On examination, the patient had stable vital signs. Neurological examination revealed a partial neurological deficit. Multiple ecchymoses were found all over her body. The rest of the examination was unremarkable. Oxygen saturation was $92 \%$ with face-mask oxygen. A left thoracostomy drain was inserted on a clinical basis. She was managed in the intensive care unit (ICU). A computed tomography scan of the chest (CT chest) and neck revealed a manubriosternal dislocation fracture, bilateral haemothorax with lung contusions and fractures of dorsal vertebrae T5, T6 and T7 (Fig. 1A - C). After initial management at the emergency department, she was kept in the ICU. Even with well-managed treatment, the patient remained in persistent neurogenic shock due to acute spinal cord injury, and had severe hypotension and bradycardia from thoracic spine trauma. On day 3 of admission she developed cardiovascular dysfunction that was unresponsive to any therapeutic manoeuvres. The patient did not respond to resuscitation measures and subsequently died.

\section{Discussion}

Epidemiology

Sternal dislocation may present as manubriosternal joint dislocation (MSJD) or sternal segment dislocation. ${ }^{[4]}$ Manubriosternal dislocations are a rare occurrence, representing $17.6 \%$ of lesions of the sternum, corresponding to $<0.5 \%$ of all traumatic lesions. ${ }^{[1-3,5]}$ Of 250 fatal road accidents, this type of lesion was observed in 13 patients, and was associated with fracture of the thoracic spine in just 3 individuals. ${ }^{[2]}$ Fowler et al ${ }^{[6]}$ reported 21 patients with dislocation fractures of the sternum, in 9 of whom fractures of the thoracic vertebrae were diagnosed. In another analysis of 1124 motor-vehicle collision victims over a 3-year period, an increase of sternal injury from $0.7 \%$ to $4 \%$ occurred, and the increase was mainly associated with the introduction of seat belts. ${ }^{[7]}$

Pathophysiology and classification Sternal injuries are frequently caused by falls from heights, or indirect trauma due to spinal flexion-compression injury. The most common mechanisms accounting for sternal fractures are motor vehicle collisions and blunt trauma to the chest and abdomen. ${ }^{[8]}$ Some

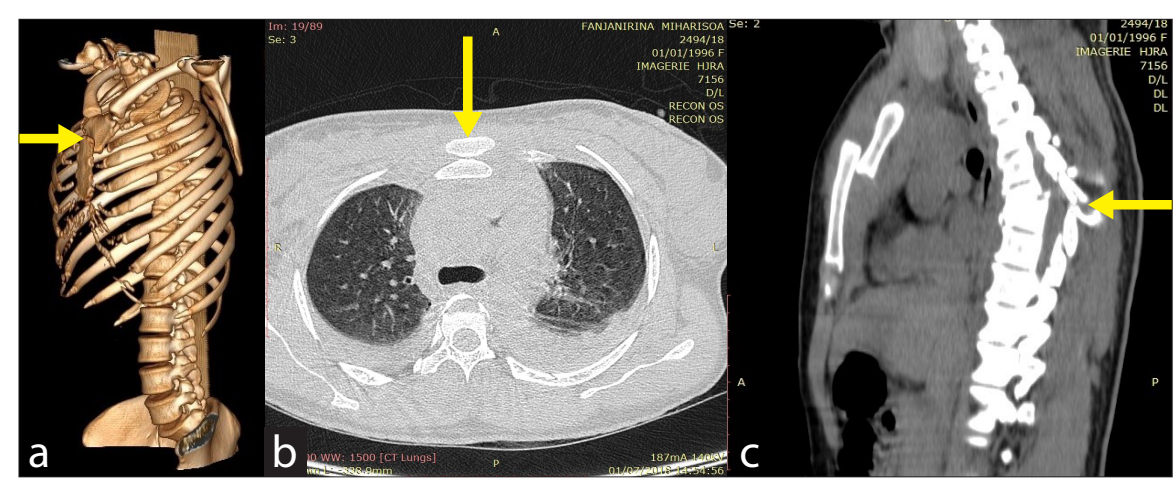

Fig. 1. (a) Left sagittal view of $3 D$ CT scan showing manubriosternal joint dislocation type II: anterior dislocation of the sternal body; (b) Axial CT scan showing manubriosternal joint dislocation and bilateral haemothorax; (c) Sagittal CT image showing three column injuries: fracture of body of dorsal vertebrae T5, T6, T7. (CT = computed tomography.) 
morphological characteristics, such as kyphoscoliosis of the thoracic spine and joint alterations in patients with rheumatoid arthritis, predispose patients to manubriosternal luxation. ${ }^{[2,9,10]}$ Thirupathi and Husted ${ }^{[1]}$ distinguished two types of manubriosternal dislocations: the sternal body may be dislocated either posteriorly (type I) or anteriorly (type II) to the manubrium. Direct injury to the chest is the mechanism usually involved in type I (usually seen with direct impact or compression injury to the anterior chest), ${ }^{[3]}$ whereas deceleration injuries resulting in hyperflexion with compression injury to the upper thorax, rheumatoid disease and kyphosis are the predisposing factors for type II. It is usually associated with flexion-compression upper thoracic spine fractures, and requires tremendous force. ${ }^{[4,12]}$ The most common associated injuries are rib fractures, pulmonary contusion, pneumothorax and extremity fractures. One study showed an $18 \%$ incidence of myocardial contusion associated with sternal fractures. ${ }^{[12]}$ Type II injuries may be associated with injuries to the aorta, other great vessels, the trachea and the oesophagus, which are potentially lifethreatening. ${ }^{[13]}$ In our patient, the manubrium was posteriorly displaced, categorising it as type II, and the mechanism was flexion-compression caused by indirect trauma.

\section{Diagnosis}

Clinical examination of the patient is essential in the diagnosis of manubriosternal luxation/dislocation, and can reveal deformity and pain in the region of the manubriosternal joint. Gopalakrishnan et al. ${ }^{[14]}$ state that in the absence of any clinical signs, mediastinal widening is due to paravertebral haematoma in the absence of aortic injury. In our case, the contrast CT chest did not show any mediastinal or vascular injury. Micro-CT is an effective tool for the diagnostic evaluation and therapeutic management of sternum anatomy. In addition to diagnosis, it is necessary to measure the length of the screws in osteosynthesis, and to calculate whether the sternum will be amenable to effective plate and screw fixation. Screw lengths should be no greater than $21 \mathrm{~mm}$, and no less than $5.2 \mathrm{~mm} .{ }^{[15]}$

\section{Indications for therapeutics}

A systematic review of the literature published from 1990 to June 2017 concluded that treatment of traumatic sternal fractures and dislocations is an underexplored topic, because limited research has been performed on indicated treatment outcomes. ${ }^{[5]}$

The first case of surgical correction of the sternal fracture was described by McKim ${ }^{[16]}$ in 1943. Surgical stabilisation of traumatic sternal fractures and dislocations without associated lesions remains controversial, and requires an individualised decision. Most (>95\%) sternal injuries are treated conservatively. In general, non-operative treatment is preferred for undisplaced fractures or dislocations. Woo ${ }^{[17]}$ reported on the conservative treatment of manubriosternal dislocation, consisting of manipulative hyperflexion reduction and rest, but no prognosis for this method of treatment was provided. ${ }^{[18]}$ Similarly, Pidcoe et al. ${ }^{[18]}$ suggested rehabilitation of type II manubriosternal dislocation consisting of progressive compressive and tensile loads placed on the non-union, which appears to stimulate the recovery process. ${ }^{[18]}$ This technique is called 'distraction osteogenesis', and is indicated favourably for the treatment of pseudarthrosis or malunion of dislocation. ${ }^{[19]}$ However, as reported by Harston and Roberts, ${ }^{[20]}$ surgical fixation is indicated in cases of displaced fractures, persistent pain affecting respiration, chronic non-union and sternal instability. ${ }^{[3,4]}$ Operative treatment is also indicated to avoid a complication such as manubriosternal septic arthritis. ${ }^{[10]}$

In the paediatric population, Murala and Nunn ${ }^{[21]}$ recommend operative immobilisation of the joint (not necessarily anatomically perfect reduction) through a small incision, in symptomatic children with traumatic manubriosternal dislocation, to relieve pain and prevent further deformity. The joint remodels itself in a growing child.

Various operative procedures using plates, wire loops, Kirschner wires or polydioxanone loops have been described in the literature. ${ }^{[1,22]}$ Schmitz et al. ${ }^{[23]}$ report a resection arthroplasty for luxation of the manubriosternal joint in rheumatoid arthritis, with success. The excision of a manubriosternal synchondrosis already damaged by a traumatic event, and the cuneiform chondrectomy of the third and fourth rib cartilage bilaterally, was the technique used by Divisi et al., ${ }^{[24]}$ with an acceptable outcome. Use of demineralised bone matrix can facilitate bone callus formation, owing to the osteo-inductive activity and the compatibility of the surrounding blood cells. ${ }^{[22]}$ Klei et al..$^{[5]}$ undertook a systematic review of current treatment and outcomes of traumatic sternal fractures, and concluded that both surgical and conservative treatment of traumatic sternal fractures and dislocations seem to be safe and effective. All patients evaluated in this review displayed sternal healing, while reported complication rates were as low as $3 \%$.

Manubriosternal injury represents a serious injury, due to commonly associated potentially life-threatening injuries. Some authors have reported mortality rates in patients with sternal fractures ranging from $24 \%$ to $45 \%{ }^{[8]}$ This high mortality rate is due to associated thoracic, pulmonary, cardiac and spinal injuries. ${ }^{[8]}$

\section{Conclusion}

The paucity of literature on Type II MSJD with concomitant spinal fracture has delayed a consensus on its surgical management. We conclude that a CT chest with contrast is indicated to rule out visceral injuries, and to plan intra-operative surgical technique. We recommend that operative treatment is indicated to avoid complications associated with manubrosternal dislocation.

Acknowledgements. None.

Author contributions. Equal contributions.

Funding. None.

Conflicts of interest. None.

1. Shaikh F, Shahabuddin S, Rashid H, Shahzad N. Surgical management of traumatic manubriosternal dislocation with locking compression plate: A case report and review of literature. Int J Med Rev Case Report 2017:1(1):20-22. https://doi.org/10.5455/ijmrcr.surgical-management-traumatic-manubriosternal-dislocation

2. Da Silva Herrero C, Porto M, Nogueira-Barbosa M, Defino H. Occult manubriosternal joint injury associated with fracture of the thoracic spine. Revista Brasileira de Ortopedia (English Edition) 2011;46(2):211-214.

3. Kothari M, Saini P, Shethna S, Dalvie S. Manubriosternal dislocation with spinal fracture: A rare cause for delayed haemothorax. Chin J Traumatol 2015;18(4):245248. https://doi.org/10.1016/j.cjtee.2014.12.001

4. Soysal O, Akdemir O, Ziyade S, Ugurlucan M. Management of sternal segment dislocation in a child with closed reduction. Case Report Med 2012:676873. https:// doi.org/10.1155/2012/676873

5. Klei DS, de Jong M, Öner F, Leenen L, van Wessem K. Current treatment and outcomes of traumatic sternal fractures - a systematic review. Int Orthopaed 2019;46(6):14551464. https://doi.org/10.1007/s00264-018-3945-4 
6. Fowler A. Flexion-compression injury of the sternum. J Bone Joint Surg Brit 1957;39B(3):487-497. https://doi.org/10.1302/0301-620x.39b3.487

7. Porter R, Zhao N. patterns of injury in belted and unbelted individuals presenting to a trauma centre after motor vehicle crash: Seat belt syndrome revisited. Ann Emerg Med 1998;32(4):418-424. https://doi.org/10.1016/s0196-0644(98)70169-6

8. Scheyerer M, Zimmermann S, Bouaicha S, Simmen H, Wanner G, Werner C. Location of sternal fractures as a possible marker for associated injuries. Emerg Med Int 2013:407589. https://doi.org/10.1155/2013/407589

9. Kelly M, Hopkinson N, Zaphiropoulos G. Manubriosternal joint dislocation in rheumatoid arthritis: The role of thoracic kyphosis. Ann Rheum Dis 1986;45(4):345348. https://doi.org/10.1136/ard.45.4.345

10. Nwaejike N, Unsworth-White M. Manubriosternal subluxation/dislocation can lead to manubriosternal septic arthritis in patients with kyphoscoliosis. Ann Royal Coll Surg Eng 2010;92(2):e35-e37. https://doi.org/10.1308/147870810x476755

11. Thirupathi R, Husted C. Traumatic disruption of the manubriosternal joint. A case report. Bull Hosp Joint Dis Orthopaed Inst 1982;42(2):242-247.

12. Smith M. Manubriosternal joint dislocation in contact sport. Emerg Med J 2001;18(6):488-489. https://doi.org/10.1136/emj.18.6.488

13. El Ibrahimi A, Sbai H, Kanjaa N, et al. Traumatic manubriosternal dislocation: A new method of stabilisation postreduction. J Emerg Trauma Shock 2011;4(2):317. https:// doi.org/10.4103/0974-2700.82237

14. Gopalakrishnan K, el Masri W. Fractures of the sternum associated with spinal injury. J Bone Joint Surg Brit 1986;68-B(2):178-181. https://doi.org/10.1302/0301620x.68b2.3957997

15. Lindner J, Douglas L, Seligson D, Waddell S, Voor M. Orthopaedic anatomy of the sternum: A micro-CT study to guide the fixation of sternal fractures. Biol Eng Med 2017;2(2)1-4. https://doi.org/10.15761/bem.1000118
16. McKim L. A method of fixation for fractures of the sternum. Ann Surg 1943;118(1):158-160.

17. Woo CC. Traumatic manubriosternal joint subluxations in two basketball players. J Manipulative Physiol Ther 1988;11(5):433-437. https://www.ncbi.nlm.nih.gov/ pubmed/3235931 (accessed 5 September 2019).

18. Pidcoe P, Burnet E. Rehabilitation of an elite gymnast with a type II manubriosternal dislocation. Phys Ther 2007;87(4):468-475. https://doi.org/10.2522/ptj.20060275

19. Press J, Zuckerman JD, Gallagher M, Cuomo F. Treatment of grade III acromioclavicular separations: Operative versus non-operative management. Bull Hosp Jt Dis 1997;56:77-83.

20. Harston A, Roberts C. Fixation of sternal fractures: A systematic review. J Trauma Injury Crit Care 2011;71(6):1875-1879. https://doi.org/10.1097/TA.0b013e31823c46e8

21. Murala J, Nunn G. Management of traumatic manubriosternal dislocation in children. J Thoracic Cardiovasc Surg 2009;138(2):517-518. https://doi.org/10.1016/j. jtcvs.2009.01.029

22. Crisci R, Divisi D. Chest wall surgical stabilisation after thoracic trauma: Indications and techniques. Shanghai Chest 2017;1:5. https://doi.org/10.21037/shc.2017.05.04

23. Schmitz MWJL, de Waal Malefijt M, van Heereveld HAEM. Resection arthroplasty for luxation of the manubrio-sternal joint in rheumatoid arthritis - a case report. Acta Orthopaedica 2010;81(3):405-406. https://doi.org/10.3109/17453674.2010.480940

24. Divisi D, di Leonardo G, Crisci R. Surgical management of traumatic isolated sternal fracture and manubriosternal dislocation. J Trauma Acute Care Surg 2013;75(5):824829. https://doi.org/10.1097/ta.0b013e3182a686a5

Accepted 20 May 2019 